Available online at: http://journal.unj.ac.id

Jurnal

Pensil

Pendidikan Teknik Sipil

Journal homepage: http://journal.unj.ac.id/unj/index.php/ipensil/index

\title{
ANALISA KUAT TEKAN TERHADAP VARIASI BEBAN PEMODELAN DINDING CANTILEVER MENGGUNAKAN SAP 2000
}

\section{ANALYSIS OF COMPRESSIVE STRENGTH OF LOAD VARIATIONS OF CANTILEVER WALL MODELING USING SAP 2000}

\author{
Amelia Rosana Putri', Jefrizal Sihombing, Yoga Satria Iswandaru, Widya Utama \\ Institut Teknologi Sepuluh Nopember, Jalan Teknik Kimia, Keputih, Kec. Sukolilo, Surabaya, \\ Jawa Timur 60111, Indonesia \\ 1ameliaadict@gmail.com
}
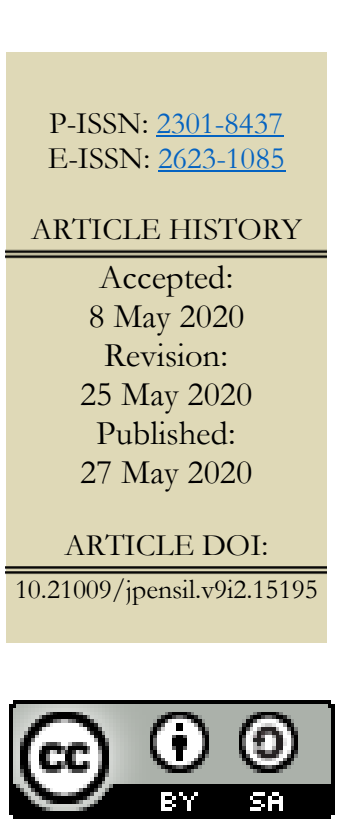

Jurnal Pensil : Pendidikan Teknik Sipil is licensed under a Creative Commons Attribution-SbareAlike 4.0 International License (CC BY-SA 4.0).

\section{Abstrak}

Pembangunan dinding penahan tanah yang tergolong sederhana perlu mempertimbangkan model, analisis materian dan perhitungan longsoran yang akan jatuh pada dinding penahan tanah. Penelitian ini menggunakan metode pemodelan dinding penahan tanah dengan metode perhitungan SAP 2000. Pemodelan dinding ini menggunakan dinding tipe kantilever dengan tinggi $550 \mathrm{~cm}$ dan lebar $385 \mathrm{~cm}$. pemodelan ini berguna untuk menghitung kekuatan minimum dinding kantilever untuk menahan tanah di Jalan Balerejo Kalegen. Selanjutnya, dinding ini dimodelkan memiliki lebar $55 \mathrm{~cm}$, lebar tumit $130 \mathrm{~cm}$, lebar kaki $130 \mathrm{~cm}$, berikut lebar kaki $100 \mathrm{~cm}$, dengan dinding yang dibenamkan sedalam $50 \mathrm{~cm}$ dan digunakan variasi beban merata, yang telah disesuaikan dimana beban yang digunakan adalah 11.138, 5.5, 0.3869 ton. Pada saat menginput data ke dalam SAP 2000 terlebih dahulu harus dilakukan perhitungan terkait gaya yang akan mempengaruhi dinding, dilanjutkan dengan pemodelan dinding sesuai dengan bentuk kantilever. Selanjutnya dapat dihitung kuat tekan dan kuat geser dinding kantilever yang telah dibuat dimana kuat tekan yang dihasilkan dinding depan rata-rata sebesar 175,154 ton m; bagian belakang rata-rata 62.666 ton $\mathrm{m}$; tumit depan rata-rata 866,054 ton $\mathrm{m}$, dan tumit belakang rata-rata 910,463 ton $\mathrm{m}$. Berdasarkan data dan analisis desain dinding penahan tanah di ruas jalan Balarejo, kuat tekan rata-rata untuk dinding depan adalah 175,154 ton $\mathrm{m}$. Hal ini menunjukkan bahwa penahan tanah sangat baik dibandingkan dengan tekanan dari tanah yang akan diterima.

Kata kunci: dinding penahan tanah, software SAP 2000, tekanan rasio

\section{Abstract}

The construction of a retaining wall that is classified as simple is necessary to consider the model, analysis of the material, and the calculation of the avalanche that will fall on the retaining wall. This study used the modelling method of retaining wall with the calculation method of SAP 2000. This wall modelling used a Cantilever type wall with a height of $550 \mathrm{~cm}$ and a width of $385 \mathrm{~cm}$. This modelling is useful to calculate 
the minimum strength of the cantilever wall for retaining the soil at the Balerejo Kalegen road. Further, this wall was modelled to have a width of $55 \mathrm{~cm}$, a heel width of $130 \mathrm{~cm}$, a foot width of $130 \mathrm{~cm}$, the following foot width of $100 \mathrm{~cm}$, with a wall that was embedded with a depth of $50 \mathrm{~cm}$ and used evenly distributed load variations, which has been adjusted where the load used were 11.138, 5.5, 0.3869 tons. When inputting data into SAP 2000 beforehand, calculations must be made related to the force that will affect the wall, followed by wall modelling according to the Cantilever shape. Subsequently, the compressive and shear strength of the Cantilever wall that has been made can be calculated where the compressive strength produced of the front wall has an average of 175.154 tons $m$; that of the back has an average of 62.666 tons $\mathrm{m}$; that of the front heel has an average of 866.054 tons $\mathrm{m}$, and that of the back heel has an average of 910.463 tons $m$. Based on the data and analysis of the design of the soil retaining wall in the Balarejo road section, the average compressive strength for the front wall is 175.154 tons $m$. It shows that the soil retainer is very good compared to the pressure from the soil that will be received.

Keywords: retaining wall, SAP 2000 software, and stress ratio

\section{Pendahuluan}

Tanah longsor merupakan salah satu kejadian alam yang terjadi pada daerah dataran tinggi, terutama di musim hujan. Kondisi iklim di Indonesia yang berupa tropis basah, menyebabkan potensi tanah longsor menjadi tinggi. Tanah longsor terjadi karena dua faktor utama yaitu faktor pengontrol dan faktor pemicu. Faktor pengontrol adalah faktor-faktor yang memengaruhi kondisi material itu sendiri seperti kondisi geologi, kemiringan lereng, litologi, sesar dan kekar pada batuan. Faktor pemicu adalah faktor yang menyebabkan bergeraknya material tersebut seperti curah hujan, gempabumi, erosi kaki lereng dan aktivitas manusia (Naryanto, 2017, p. 2).

Tanah longsor sangat berbahaya untuk aktivitas manusia, seperti halnya pada jalanan yang berada pada daerah lereng. Jalan tersebut rawan terjadi longor apalagi ketika musim hujan. Untuk mengatasi hal tersebut dibuatlah dinding penahan tanah pada jalan yang dianggap rawan terjadi longsor. Dinding penahan tanah (Retaining Wall) adalah bangunan yang berfungsi menstabilkan tanah pada kondisi tanah tertentu khususnya untuk daerah lereng.
Ketika kondisi tanah terganggu akibat beberapa hal tertentu, seperti tanah longsor dan lain-lain yang dapat menurunkan sifat fisik dan sifat mekanik dari parameter tanah, maka akan terjadi kerusakan struktur dan membahayakan aktivitas manusia (Meliania, 2017, p. 1).

Untuk meminimalisir kondisi tersebut, pada tulisan ini akan dilakukan perencanaan dinding penahan tanah pada daerah lereng menggunakan software (SAP 2000). Sehingga dinding penahan tanah tersebut diharapkan dapat mengurangi resiko tanah longsor pada daerah lereng.

\section{Dasar Teori}

\section{Kuat Tekan}

Kuat tekan adalah kemampuan untuk menahan gaya tekan persatuan luas. Kuat tekan mengidentifikasikan mutu dari sebuah struktur. Besarnya kuat tekan menurut (Sari, 2019, p. 135), dapat dihitung dengan persamaan:

$$
P=\frac{F}{A}
$$

Keterangan :

$\mathrm{P}=$ kuat tekan $\left(\mathrm{N} / \mathrm{mm}^{2}\right)$ 
$\mathrm{F}=$ beban tekan maksimum $(\mathrm{N})$

$\mathrm{A}=$ luas penampang benda uji yang ditekan $\left(\mathrm{mm}^{2}\right)$

Nilai kuat tekan juga berhubungan dengan nilai modulus elastisitas, jika tekanan yang diberikan melebihi batas elastisitas suatu bahan, maka bahan tersebut akan pecah. Dimana stress adalah gaya yang menyebabkan deformasi dibagi dengan daerah di mana gaya diterapkan dan strain adalah rasio perubahan dalam beberapa parameter yang disebabkan oleh deformasi dengan nilai asli dari parameter.

\section{Tegangan Geser}

Tegangan geser tanah adalah gaya perlawanan yang dilakukan butir-butir tanah terhadap desakan atau tarikan. Bila gaya geser bekerja pada permukaan, maka bekerja pula tegangan normal, harga $\tau$ akan membesar akibat deformasi mencapai harga batas. Karakteristik kekuatan dari tanah yang dinyatakan oleh Kartini (Kartini, 2017, p. 1) dalam persamaan Coulomb.

$$
\tau=c+\sigma \tan \phi
$$

dengan,

$\tau=$ Tegangan geser,

$\mathrm{c}=$ Kohesi tanah,

$\phi=$ Sudut geser tanah, dan

$\sigma=$ Tegangan normal yang bekerja.

\section{Gaya Lintang/Bidang Geser dan Momen}

Gaya lintang (shear forces diagram) adalah susunan gaya yang tegak lurus dengan sumbu batang. gaya lintang akan positif apabila perputaran gaya yang bekerja searah dengan jarum jam dan diarsir tegak lurus dengan sumbu batang yang menerima gaya melintang atau sebaliknya bila perputaran gaya yang bekerja berlawanan arah dengan perputaran jarum jam diberi tanda negatif dan diarsir sejajar dengan sumbu batang.
Menurut Nurmasyitah, (2016, p. 14) momen adalah hasil kali antara gaya dengan jaraknya jarak, disini adalah jarak tegak lurus dengan garis kerja gayanya berarti bahwa pada titik terjadi momen sebesar:

$$
M c=R A \cdot L 1
$$

\section{Dinding Penahan Tanah}

Dinding penahan tanah merupakan dinding yang digunakan untuk menahan beban tanah secara vertikal ataupun terhadap kemiringan tertentu. Dinding dinding penahan adalah konstruksi yang digunakan untuk memberikan stabilitas tanah atau bahan lain yang kondisi massa bahannya tidak memiliki kemiringan alami, dan juga digunakan untuk menahan atau menopang timbunan tanah atau onggokan material lainnya.

Dalam perencanaan sebuah dinding penahan tanah, perlu diambil dimensi tertentu sehingga dinding yang direncanakan mungkin untuk dikerjakan, cukup stabil dan kuat. Pengambilan dimensi awal dinding penahan tanah juga sangat ditentukan dengan bentuk lereng dan tanah yang kan ditahannya.

\section{SAP 2000}

Seri program SAP merupakan salah satu program analisis dan perancangan struktur yang telah dipakai secara luas diseluruh dunia, program ini merupakan hasil penelitian dan pengembangan oleh tim dari University of California, yang dipimpin Prof.Edward L. Wilson selama lebih dari 25 tahun. Sistem yang berbasis grafis membuat proses pembuatan model, pemeriksaan, dan penampilan hasil dapat dilakukan secara interaktif pada layar (Kappos, 2002). 


\section{Metode Penelitian}

Alat dan Bahan yang digunakan dalam percobaan pemodelan ini adalah: 1) Data dari paper acuan dan 2) software SAP 2000 V.14.00. Adapun langkah kerja dapat digambarkan pada flowchat di bawah ini:

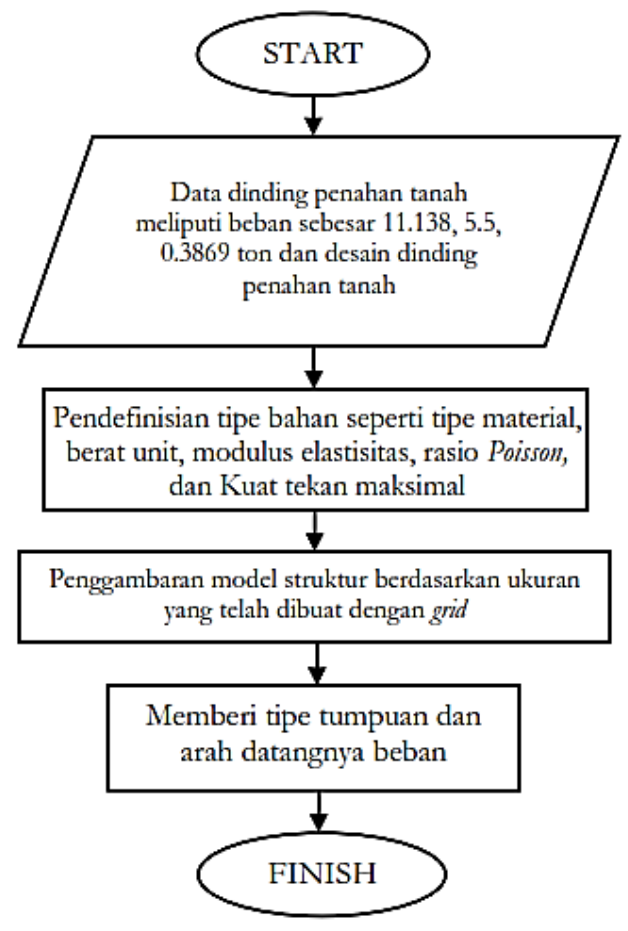

Gambar 1. Flowchart

Berdasarkan data percobaan didapatkan beberapa variasi beban merata yang akan dipakai, maka dilakukan pemodelan dinding Cantilever dimana dinding tersebut dikenai beban sebesar $11.138,5.5,0.3869$ ton lalu dimodelkan dinding Cantilever dengan menggunakan grid. Setelah itu dilakukan pendefinisian tipe bahan seperti tipe material, berat unit, modulus elastisitas, rasio Poisson, dan Kuat tekan maksimal yang ingin didapatkan. Selanjutnya digambarkan model struktur sesuai ukuran yang ingin dibuat sebelumnya.Selanjutnya dilakukan tipe tumpuan dan arah datangnya beban. Terakhir, dapat dilakukan perhitungan Kuat Tekan dan Kuat Geser pada dinding Cantilever yang telah dibuat.

\section{Data Pengukuran dan Analisa Data}

\section{Data Pengukuran}

Data yang digunakan ialah data sekunder yang didapatkan dari hasil perhitungan yaitu:

$$
\begin{aligned}
K a & =\operatorname{tg}^{2}\left(45^{\circ}-\frac{1}{2} \varphi\right) \\
& =\operatorname{tg}^{2}\left(45^{\circ}-\frac{20.14^{\circ}}{2}\right) \\
& =0.4877 \\
K p & =\operatorname{tg}^{2}\left(45^{\circ}+\frac{1}{2} \varphi\right) \\
& =\operatorname{tg}^{2}\left(45^{\circ}+\frac{20.14^{\circ}}{2}\right) \\
& =2.0502
\end{aligned}
$$

dengan Nilai Koefisien tanah aktif dilambangkan dengan $(\mathrm{Ka})$ dan Koefisien tanah pasif (Kp) dicari dengan menggunakan rumus sehingga ditemukan hasil $\mathrm{Ka}=0,4877$ dan $\mathrm{Kp}=$ 2,0502. Sehingga dapat direncanakan bentuk dinding penahan pada Gambar 2 sebagai berikut:

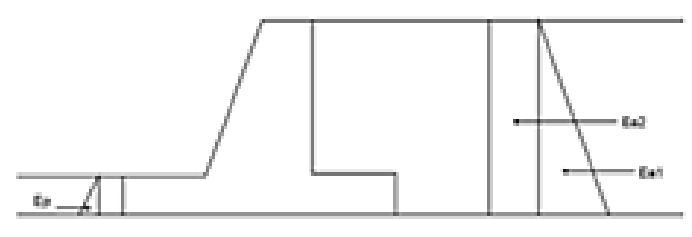

(a)

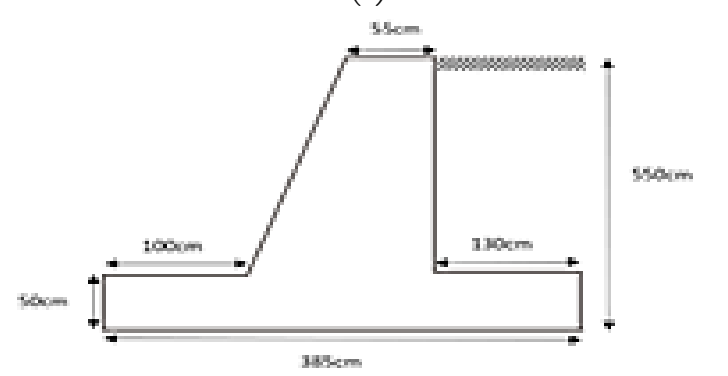

(b)

Gambar 2. Desain penahan tanah

Keterangan:

(a) Dinding penahan tanah pada umumnya,

(b) Rancangan penanahan tanah. 
Yang mana dinding ini direncanakan dan dikenai beban segitiga dalam perhitungannya. Dinding masuk dalam tanah $0,5 \mathrm{~m}$ dari perhitungan hasil bebannya, dengan $E a=12 \times h 12 \times \gamma t \times K a$, maka $E a$ $=\mathbf{1} \mathbf{2} \times 5,52 \times 1,51 \times 0,4877=11,138$ ton. Kemudian hasil $E a 2=h x \gamma w$, yaitu $E a 2$ 5,5x 1 = 5,5 ton; dan Ep = $12 \times h 22 x \gamma t$ $x, E p=12 x 0,5 x 1,51 x 2,0502=0,3869$ ton. Dari hasil yang telah didapatkan dapat direncanakan dinding penahan tanah seperti gambar diatas yang mana didapatkan hasil sebagai berikut:

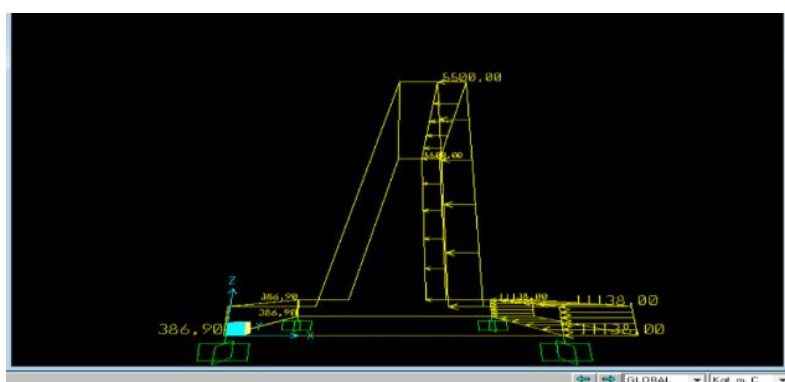

(a)

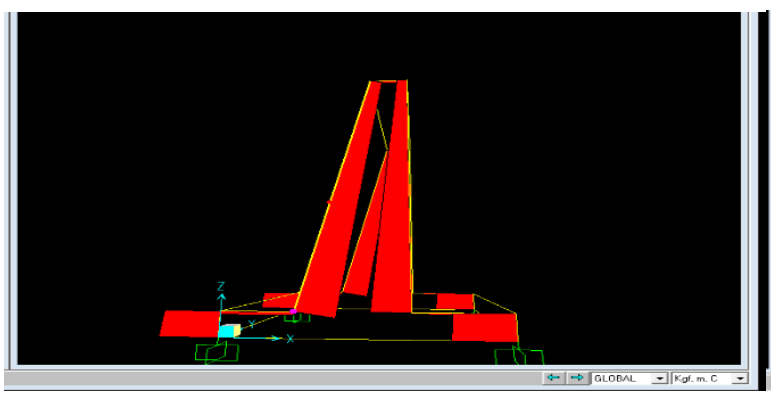

(c)

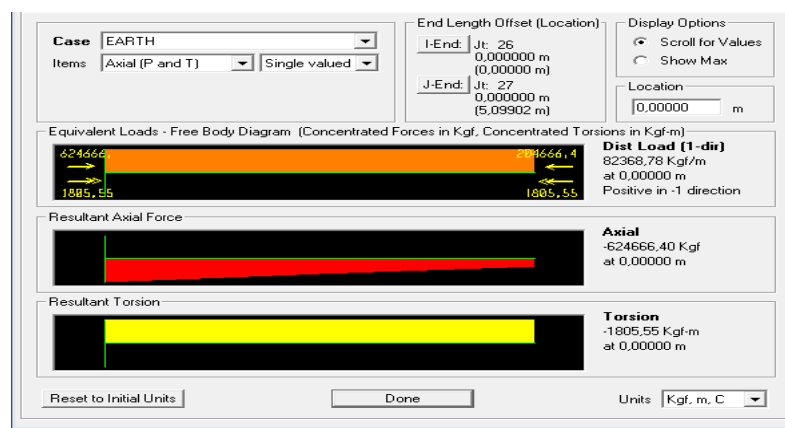

(e)

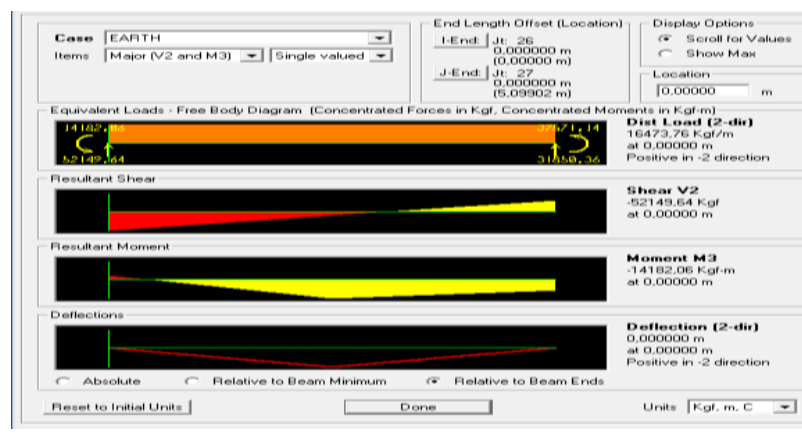

(f)

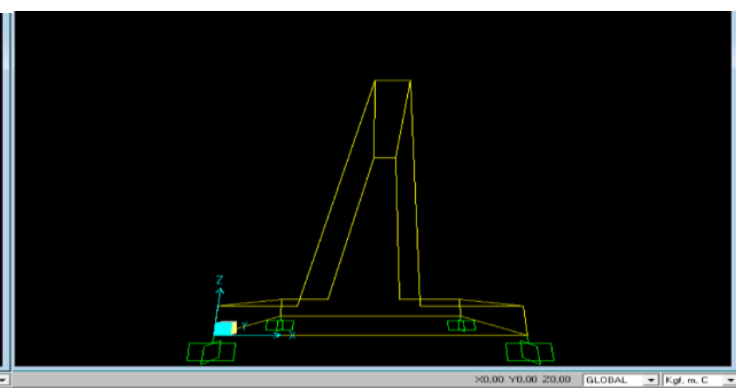

(b)

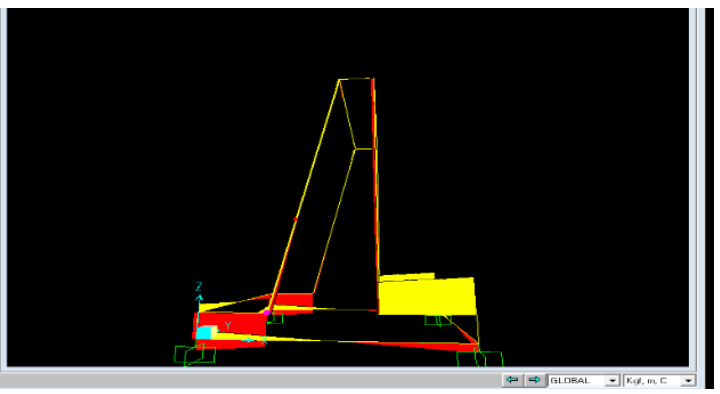

(d)
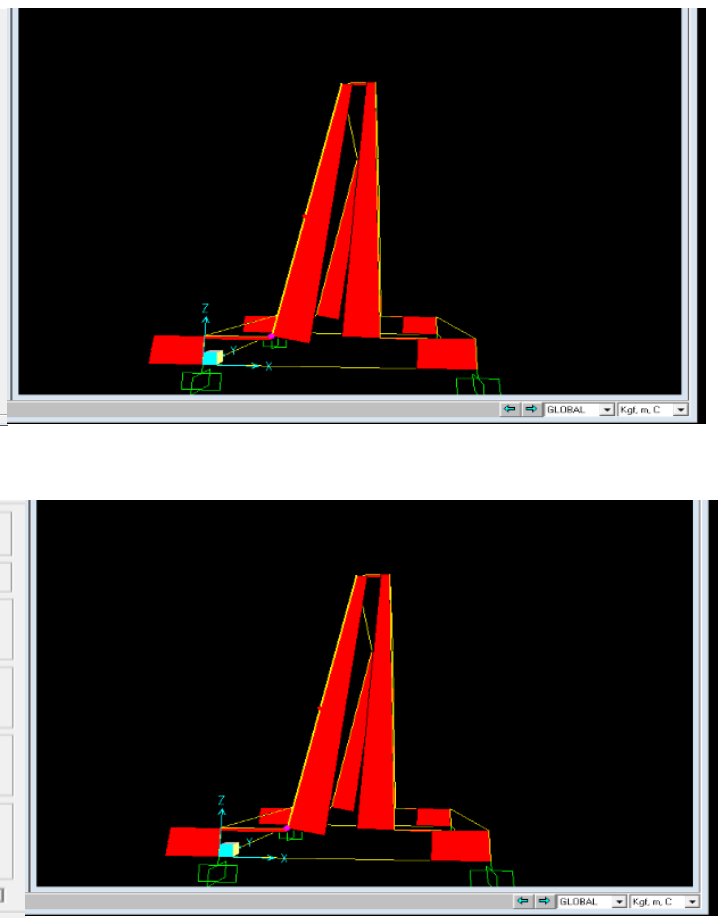

$\Rightarrow \Rightarrow$ G

Gambar 3. Desain dan penggambaran penahan tanah dengan software SAP 2000 
Keterangan: (a) Desain dinding penahan tanah. (b) Dinding penahan tanah saat dikenai beban 11,138 ton, 5,5 ton, dan 0,389 ton. (c) Dinding penahan dikenai kuat tekan oleh penambahan beban. (d) Dinding penahan dikenai kuat geser oleh penambahan beban. (e) Penggambaran hasil perhitungan kuat tekan pada setiap sisi dinding penahan tanah. (f) Penggambaran hasil perhitungan kuat geser pada setiap sisi dinding penahan tanah.

\section{Hasil Penelitian dan Pembahasan}

Berdasarkan data yang diperoleh, nilai beban merata yang akan diujikan pada dinding Cantilever sebesar 11.138, 5.5, 0.3869 ton diperoleh dari hasil perhitungan yang akan diolah menggunakan software SAP 2000. Berdasarkan pemodelan tersebut digunakan rancangan dinding penahan tanah yang di design sesuai kondisi aktual yang telah diperhitungkan yang dapat diketahui dari gambar 4.2 dan 4.3 dimana memiliki tinggi dinding, lebar bawah, lebar atas, lebar tumit, lebar kaki dengan dinding penahan tanah yang masuk kedalam tanah, berturut turut dengan nilai $550 \mathrm{~cm}, 385 \mathrm{~cm}, 55 \mathrm{~cm}$, $130 \mathrm{~cm}, 100 \mathrm{~cm}$ dan $50 \mathrm{~cm}$. Pada gambar 4.4 Setelah dilakukan pemodelan dapat diinputkan beban yang akan dikenai pada dinding penahan. Dapat diketahui beban pada dinding penahan arahnya berasal dari sisi belakang dinding Cantilever, serta sisi depan bagian bawah dinding Cantilever dengan beban yang diinputkan ialah variasi beban merata di setiap sisi dindingnya. Berdasarkan gambar 4.5 dan 4.6 dapat diketahui apabila dinding Cantilever dilakukan perhitungan kuat tekan (digambarkan dengan warna merah). Setiap sisi dan titiknya dapat diketahui nilai perhitungan kuat tekan yang rata-ratanya sebesar 175,154 ton $\mathrm{m}$, bagian belakang 624,666 ton m, bagian tumit depan sebesar 866,054 ton $\mathrm{m}$, bagian tumit belakang 910,463 ton $\mathrm{m}$. Dan nilai kuat geser pada hasil permodelan sebesar 161,700 ton $\mathrm{m}$. Selanjutnya pada gambar 4.7 dan 4.8 ialah keterangan gambar tentang kuat geser yang telah dilakukan perhitungan, dimana kuat geser pada pemodelan ini terletak pada sisi belakang pemodelan dinding Cantilever yang rata-ratanya sebesar 161,700 ton $\mathrm{m}$. Selanjutnya dilakukan analisa kekuatan dinding penahan tanah dengan membandingkan besar tekanan tanah terhadap dinding dengan kuat tekan dinding tersebut. Pada paper sebelumnya, besar tekanan total tanah terhadap dinding adalah 35,473 ton m. Dari sini dapat diamati, bahwa permodelan dinding penahan tanah tersebut sudah memiliki ketahanan yang cukup dimana kuat tekan dinding tersebut lebih besar dari pada tekanan tanah yang mengenai dinding.Hal tersebut juga dapat digambarkan dengan garis pada SAP 2000 berwarna jingga yang artinya dinding tersebut cukup menahan tekanan. Terakhir dilakukan analisis bagaimana hubungan kuat geser terhadap beban yang dialami dinding. Pada data sebelumnya, beban yang dialami oleh dinding sebesar 156,6 ton m sedangkan kuat geser dari hasil permodelan menggunakan SAP2000 dan variasi bahan saat ini ialah sebesar 161,700 ton $\mathrm{m}$.

\section{Simpulan}

Berdasarkan data dan analisa permodelan desain dinding penahan tanah di daerah ruas jalan Balarejo, didapatkan hasil kuat tekan rata-rata untuk dinding bagian depan sebesar 175,154 ton $\mathrm{m}$, bagian belakang 624,666 ton $\mathrm{m}$, bagian tumit depan sebesar 866,054 ton $\mathrm{m}$, bagian tumit belakang 910,463 ton m dimana kuat tekan dinding penahan tanah tersebut sudah sangat baik jika dibandingkan dengan tekanan yang akan diterima dinding dari tanah yaitu sebesar 35,473 ton. Sedangkan nilai kuat geser dari hasil permodelan didapatkan ialah 161,700 ton $\mathrm{m}$.

Adapun saran yang kami berikan untuk kedepannya adalah: 1) Untuk membangunan centilever wall kami menyarankan agar terlebih dahulu menganalisa kondisi tanah yaitu kestabilan tanahnya sebagai bahan pertimbangan dalam pembuatan desain centilever wall yang di perlukan, dan 2) Untuk melakukan pemodelan desain dinding penahan tanah kami menyarankan 
menggunakan SAP2000 dimana dapat mempermudah menganalisa faktor-faktor mekanik pada dinding.

Untuk rencana tindak lanjut kedepan, agar lebih memahami perancangan desain dinding penahan tanah menggunakan SAP2000, perlu dilakukan praktikum dengan data hasil penelitian sendiri.

\section{Daftar Pustaka}

Abdul, H., \& Mulya, R. (2011). Studi Stabilitas Dinding Penahan Tanah Kantilever pada Ruas Jalan Silang Padang-Bukittinggi KM $64+500$. Jurnal Rekayasa Sipil 7(1).

Achmad, F. (2010). Tinjauan Longsor pada Ruas Jalan Akses-Pelabuhan Gorontalo. Jurusan Teknik Sipil Fakultas Teknik Universitas Negeri Gorontal. Simposium XIII FSTPT. Semarang: Universitas Katholik Soegijapranata Semarang.

Beer, F. (2009). Mechanics of Materials. New York: McGraw Hill.

Buwono, H., \& Hanif, B. (2016). Simulasi Stabilitas Tanah Berkohesi Rendah Akibat Penggunaan Soldier Pile dengan Pemodelan Plaxis dan GeoStudio. Seminar Nasional Sains dan Teknologi . Jakarta: Jurusan Teknik Sipil Universitas Muhammadiyah Jakarta.

Hartini, R., Redana, I., \& Wardana, I. (2014). Kerawanan Longsor Lereng Jalan Studi Kasus Ruas Jalan SukasadaCandi Kuning. Jurnal Spektran 2(2).

Kappos, A. (2002). Seismic Design and Assessment of Bridges: Inelastic Methods of Analysis and case studies. New York: Springer dorcdrecht Heidelberg .

Kartini. (2017). PENENTUAN SUDUT GESER DALAM DASAR PADA BATUAN TERKEKARKAN. Lampung: Universitas Lampung Mangkurat.

Meliania, K. (2017). Analisis Stabilitas Dinding Penahan Tanah (Studi Kasus: Sekitar Areal PT Trakindo, Desa Maumbi,
Kabupaten Minahasa Utara). Manado: Universitas Sam Ratulangi Manado.

Muntohar, A. (2006). Mekanisme Keruntuhan Lereng Tegak dan Teknik Perkuatan dengan Geotekstil. Jurnal Teknik Sipil 7(2).

Naryanto. (2017). Analisis Kejadian Bencana Tanah Longsor Tanggal 12 Desember 2014 Di Dusun Jemblung, Desa Sampang, Kecamatan Karangkobar, Kabupaten Banjarnegara, Provinsi Jawa Tengah. Tangerang Selatan: Pusat Reduksi Risiko Bencana (PTRRB).

Nurmasyitah. (2016). TUMPUAN PADA JEMBATAN, GAYALINTANG DAN MOMEN. Banda Aceh: Universitas Syiah Kuala Darussalam.

Nurrohman, I., \& Surjandari, N. (2017). Analisis Dinding Penahan Tanah Tipe Gravitasi pada Lereng di desa Sumbersari, Tirtomoyo, Wonogiri. . EJumal Matriks Teknik Sipil.

Pangemanan, V. (2014). Analisis Kestabilan Lereng dengan Metode Fellenius. Jumal Teknik Sipil Statik 2(1).

Putra, T., \& Ardana, M. (2010). Analisis Stabilitas Lereng pada badan Jalan dan Perencanaan Perkuatan Dinding Penahan Tanah. Jurnal Ilmiah Teknik Sipil 14(1).

Ramadhani, S. (2014). Perencanaan Dinding Penahan Tipe Gravitasi pada Lokasi Bukit BTN Teluk Palu Permai. Jurnal SMARTek.

Riogilang, H., \& Pontororing, C. (2014). Soil Nailing dan Anchor Sebagai Solusi Aplikatif Penahan untuk Potensi Longsor di STA 7+250 Ruas Jalan Manado-Tomohon. Jurnal Ilmiah Media Engineering 4(2).

Safari, D. (2016). Perencanaan Struktur Dinding Penahan Tanah Type Cantilever pada Ruas Jalan SamarindaBontang Sta+850. Jurusan Teknik Sipil Universitas 17 Agustus 
Samarinda. Teknik Sipil dan Arsitektur 2(2).

Sari, M. (2019). Studi Karakteristik Relasi Parameter Sifat Fisik Dan Kuat Tekan Uniaksial Pada Contoh Batulempung, Andesit Dan Beton. Lampung: Universitas Lampung Mangkurat.

Setiawan, H. (2011). Perbandingan Penggunaan Dinding Penahan Tanah Tipe Kantilever dan Gravitasi dengan Variasi Ketinggian Lereng. Jurnal Infrastruktur 1(2).
Sudarno, L. (2017). Perencanaan Dinding Penaban Tanah Untuk Perbaikan Longsor Di Ruas Jalan Balerejo Kalegen. Magelang: Teknik Sipil.

Surendro, B. (2015). Rekayasa Fondasi Teori dan Penyelesaian Soal. Yogyakarta: Graha Ilmu.

Yanuar, A., \& Yuwana, D. (2016). Analisis Stabilitas Lereng di Kaki Gunung Sumbing. Reviews in Civil Engineering 1(1). 